\title{
Characterization of $\beta$-glucosidase of Lactobacillus plantarum FSO1 and Candida pelliculosa L18 isolated from traditional fermented green olive
}

\author{
Yahya Rokni ${ }^{1 *}$ D, Houssam Abouloifa ${ }^{1}$, Reda Bellaouchi ${ }^{1}$, Ismail Hasnaoui ${ }^{1}$, Sara Gaamouche ${ }^{1}$, Zahra Lamzira',
} Riadh B. E. N. Salah², Ennouamane Saalaoui ${ }^{1}$, Nabil Ghabbour ${ }^{1}$ and Abdeslam Asehraou ${ }^{1}$

\begin{abstract}
Background: Oleuropein, the main bitter phenolic glucoside responsible for green olive bitterness, may be degraded by the $\beta$-glucosidase enzyme to release glucose and phenolic compounds.

Results: Lactobacillus plantarum FSO1 and Candida pelliculosa L18 strains, isolated from natural fermented green olives, were tested for their $\beta$-glucosidase production and activity at different initial $\mathrm{pH}, \mathrm{NaCl}$ concentrations, and temperature. The results showed that strains produced extracellular and induced $\beta$-glucosidase, with a molecular weight of $60 \mathrm{kD}$. The strains demonstrated their biodegradation capacity of oleuropein, associated with the accumulation of hydroxytyrosol and other phenolic compounds, resulting in antioxidant activity values significantly higher than that of ascorbic acid. The highest production value of $\beta$-glucosidase was $0.91 \mathrm{U} / \mathrm{ml}$ obtained at pH 5 and $\mathrm{pH} 6$, respectively for $\mathrm{L}$. plantarum FSO1 and C. pelliculosa L18. The increase of $\mathrm{NaCl}$ concentration, from 0 to $10 \%(\mathrm{w} / \mathrm{v})$, inhibited the production of $\beta$-glucosidase for both strains. However, the $\beta$-glucosidase was activated with an increase of $\mathrm{NaCl}$ concentration, with a maximum activity obtained at $8 \% \mathrm{NaCl}(\mathrm{w} / \mathrm{v})$. The enzyme activity was optimal at pH 5 for both strains, while the optimum temperature was $45^{\circ} \mathrm{C}$ for L. plantarum FSO 1 and $35{ }^{\circ} \mathrm{C}$ for C. pelliculosa L18.
\end{abstract}

Conclusions: L. plantarum FSO1 and C. pelliculosa L18 strains showed their ability to produce an extracellular and induced $\beta$-glucosidase enzyme with promising traits for application in the biological processing of table olives.

Keywords: Olive, Oleuropein, $\beta$-Glucosidase, Lactobacillus plantarum, Candida pelliculosa

\section{Background}

Oleuropein is the main natural polyphenol glucoside responsible for olive bitterness [1]. The olive debittering process, widely practiced in the table olive industry, is based on the lye solution $(\mathrm{NaOH})$ treatment of fruits. However, this chemical process is associated with drawbacks on the consumer's health by reducing nutrients in fermented olives, and on the environment by releasing

\footnotetext{
* Correspondence: yahya.rokni@gmail.com

${ }^{1}$ Laboratory of Bioresources, Biotechnology, Ethnopharmacology and Health, Faculty of Sciences, Mohammed Premier University, BP 717, Oujda, Morocco Full list of author information is available at the end of the article
}

toxic wastewaters rich in sodium hydroxide [2]. The biological debittering of olives, based on starters with a specific enzyme, can contribute to the sustainable development of this bio-resource.

Oleuropein, an $O$-glycosylated compound composed of D-glucose $\beta$ (1-4) linked to aglycone, is reported to be hydrolyzable by the $\beta$-glucosidase enzyme, releasing $D$ glucose and aglycone $[1,3]$. The latter is subsequently hydrolyzed with esterase to simpler phenolic compounds, namely hydroxytyrosol and elenolic acid $[1,4]$. This hydrolysis plays an important role in enhancing the lactic fermentation process of olives by, providing 
glucose as a carbon source for lactic acid bacteria [5], and increasing the nutraceutical property of fermented olives with hydroxytyrosol accumulation [6].

Based on the Carbohydrate-Active Enzyme database (http://www.cazy.org, CAZy) [7], the $\beta$-glucosidase enzymes are of a class of glycoside hydrolases (EC 3.2.1-) [7]. These enzymes catalyze the hydrolysis of $\mathrm{O}$-glycosidic bonds between two or more carbohydrates or between a carbohydrate and a non-carbohydrate moiety (aglycone), leading to the release of carbohydrate and aglycone [7-9]. The $\beta$-glucosidase enzymes are widespread in microorganisms, and their genes of production can differ in strains of the same species [9].

Several studies reported the capacity of Lactobacillus strains (L. plantarum, L. casei, and L. brevis) [6, 10-12] and yeasts $[13,14]$ to produce the $\beta$-glucosidase enzyme. In previous work, we reported high in vitro $\beta$ glucosidase activity of some Lactobacillus strains, releasing glucose and hydroxytyrosol from oleuropein [15]. However, the $\beta$-glucosidase activity of $L$. plantarum strain obtained was lower in the olive brine environment and led to the production of a fermented green olive with some bitterness [16]. The in vitro biodegradation of oleuropein by $L$. plantarum was demonstrated to be dependent on the stress factors $(\mathrm{pH}, \mathrm{NaCl}$, and glucose) [6]. The conditions of production and activity of $\beta$ glucosidase of Lactobacillus and yeast strains, particularly in olive brine conditions, are not well highlighted. Further studies elucidating this biodegradation process, could improve the biological debittering process of green olives, by using selected microorganisms and/or their $\beta$ glucosidase. The main objective of this work is to study the production and activity of $\beta$-glucosidase of $L$. plantarum FSO1 and Candida pelliculosa L18 strains, isolated from traditional fermented green olives, in presence of stress factors close to olive brine environment.

\section{Methods}

\section{Microorganisms studied}

The microbial strains used in this work were Lactobacillus plantarum FSO1 and Candida pelliculosa L18, isolated in our laboratory from traditional fermented green olive brine [17]. In this traditional process, nondebittered green olives of Moroccan Picholine variety were directly brined and led to undergo a natural fermentation process, allowing the transformation of olives into an edible product.

\section{Chemicals and reagents}

All the chemicals used in this work were purchased from Sigma-Aldrich. The solvents (methanol, toluene, and acetic acid) were of analytical grade. The commercial enzyme beta-glucosidase (EC.3.2.1.21) was purchased from Sigma-Aldrich.

\section{Detection of $\beta$-glucosidase enzyme API-ZYM gallery}

The enzymatic profile of the strains of $L$. plantarum FSO1 and C. pelliculosa L18 was determined using the API-ZYM gallery (BioMerieux, France). This gallery (ref $25200)$ is a simplified semi-quantitative evaluation technique for 19 enzymes [18]. It was used to highlight the enzymatic profile of the strains, including $\beta$-glucosidase and esterase.

The 20 wells of the gallery were inoculated with $65 \mu \mathrm{l}$ of overnight cultures of L. plantarum FSO1 and C. pelliculosa L18, obtained on De Man Rogosa and Sharpe (MRS) and Yeast Extract Glucose (YEG) broth, respectively. The microbial suspensions were standardized to 56 Mac Farland. After inoculation, the gallery was incubated at $28{ }^{\circ} \mathrm{C}$ for $5 \mathrm{~h}$, then a drop of each reagent ZYM A (Ref 70494) and ZYM B (Ref 70493) was added to each well to develop the stain revealing enzyme activity. After $5 \mathrm{~min}$, a numerical value from 0 to 5 was assigned based on the evaluation of the color developed in each enzyme reaction, using the color card provided by the manufacturer $[19,20]$.

\section{Esculin-based medium}

The esculin-based medium was used to detect the $\beta$ glucosidase activity in L. plantarum FSO1 and C. pelliculosa L18, according to the method of [21]. Briefly, the medium composed of casein peptone $8 \mathrm{~g} / \mathrm{L}$, esculin sesquihydrate $1 \mathrm{~g} / \mathrm{L}$, ferric ammonium citrate $1 \mathrm{~g} / \mathrm{L}$, agar 17 $\mathrm{g} / \mathrm{L}, \mathrm{pH}$ 7.4, is autoclaved and then poured in Petri dishes. Overnight cultures $(60 \mu \mathrm{l})$ of the strains (FSO1 and L18) were drop inoculated on the medium and then incubated at $30{ }^{\circ} \mathrm{C}$ for $48 \mathrm{~h}$. Sixty microliters of $\beta$ glucosidase $(2 \mathrm{mg} / \mathrm{ml})$ and distilled water were used as positive and negative controls, respectively. After incubation of the culture assays, made in triplicate, a positive $\beta$-glucosidase activity is indicated by a black precipitate around colonies, due to the hydrolysis of esculin to glucose and esculetin. The esculetin reacts with iron III ions to form a black precipitate.

\section{Induction and localization of $\beta$-glucosidase activity}

The strains (L. plantarum FSO1 and C. pelliculosa L18) were tested for the induction and localization (extracellular, intracellular, or membrane) of $\beta$-glucosidase activity. For this, overnight cultures $(5 \mu \mathrm{L})$ of the strains (FSO1 and L18) were inoculated in $5 \mathrm{~mL}$ of normal MRS and modified MRS (MRSm), containing 1\% (w/v) of oleuropein (Extrasynthese, Genay, France) as a sole carbon source. After incubation at $30{ }^{\circ} \mathrm{C}$ for 7 days, the obtained cultures were centrifuged at $12000 \mathrm{~g}$ for 12 min at $4{ }^{\circ} \mathrm{C}$ (Hermle Labnet Z216MK). The supernatant (supernatant 1: E) obtained was separated from the pellet (cell cream). The cell cream was then resuspended in 
$0.1 \mathrm{M}$ phosphate buffer at $\mathrm{pH} 5$, and then the cells were lysed by sonication at $4{ }^{\circ} \mathrm{C}$ for $45 \mathrm{~min}$ in an ultrasonic bath (Bandelin Sonorex Digitec) with continuous and pulsed modes of $5 \mathrm{~s}$ ON/5 s OFF according to the method of Pchelintsev, Adams [22]. The lysed cells were centrifuged, at $12000 \times \mathrm{g}$ for $12 \mathrm{~min}$ at $4{ }^{\circ} \mathrm{C}$, to separate the intracellular and the membrane fractions. After these operations three fractions were obtained for each strain, the extracellular (supernatant 1: E), the intracellular (supernatant 2: I), and the membrane pellet (cell wall suspension: $M$ ) fractions. These fractions $(E, I$, and $M$ ) were used to measure the enzymatic activity.

\section{Sodium dodecyl sulfate-polyacrylamide gel electrophoresis}

The fraction E, obtained with oleuropein $(1 \%)$ as a sole carbon source, was added with $\left(\mathrm{NH}_{4}\right)_{2} \mathrm{SO}_{4} 80 \%(\mathrm{w} / \mathrm{v})$ to precipitate proteins. After overnight precipitation, the precipitates formed were collected by centrifugation at $10000 \times \mathrm{g}$ for $20 \mathrm{~min}$ at $4{ }^{\circ} \mathrm{C}$, and the pellets obtained were dissolved in $20 \mathrm{mM}$ sodium acetate buffer $\mathrm{pH}$ 5.0. The sodium dodecyl sulfate (SDS) gel was prepared with $0.1 \%$ SDS in $15 \%$ separating gels and $5.0 \%$ stacking gels (final gel concentration). Tris-glycine buffer $\mathrm{pH} 8.3$ containing $0.1 \%$ SDS was used as the electrode buffer. Discontinuous SDS-PAGE in reducing conditions was performed according to the procedure of Laemmli [23]. Samples were treated with Laemmli buffer and boiled for $10 \mathrm{~min}$ at $95^{\circ} \mathrm{C}$ before application to the gel. Electrophoresis was run from cathode to anode at $130 \mathrm{~V}, 30$ $\mathrm{mA}$ for $40 \mathrm{~min}$ at room temperature in a Mini-Gel Electrophoresis Unit (Bio-Rad). The following proteins were used for calibration: lysozyme $(14.6 \mathrm{kDa})$, esterase (28 $\mathrm{kDa}), \beta$-glucosidase $(60 \mathrm{kDa})$, bovine serum albumin $(66$ $\mathrm{kDa})$, glucose oxidase $(160 \mathrm{kDa})$. After running electrophoresis, proteins in the gel were visualized by staining with silver nitrate, according to the method of Wray et al. [24].

\section{Determination of $\beta$-glucosidase activity}

The $\beta$-glucosidase activity of the fractions $(E, I$, and $M)$ obtained from the strains (FSO1 and L18) was determined according to the method of Norkrans [25], by measuring the hydrolysis of para-nitrophenyl- $\beta$-D-glucopyranoside (p-NPG) (Merck) used as substrate. The reaction mixture contained $0.9 \mathrm{~mL}$ of p-NPG $(5 \mathrm{mM})$ in a $50 \mathrm{mM}$ citrate buffer (pH 4.8) and $0.1 \mathrm{~mL}$ of the enzymatic fraction $(E, I$, or $M)$, obtained in presence of oleuropein $(1 \%)$ as a sole carbon source. The reaction was carried out at $50{ }^{\circ} \mathrm{C}$ for $10 \mathrm{~min}$ and then stopped by the addition of $2 \mathrm{~mL}$ of $\mathrm{Na}_{2} \mathrm{CO}_{3}(1 \mathrm{M})$ and $10 \mathrm{~mL}$ of distilled water. The amount of para-nitrophenol (p-NP) released was determined by measuring its absorbance at $405 \mathrm{~nm}$. One unit of enzymatic activity (U) was defined as the amount of enzyme which produced $1 \mu$ mol of p-NP (para-nitrophenol) per min under the conditions of the experiment. A calibration curve was prepared using pNP. All the tests were carried out in triplicate.

\section{Antioxidant activity}

The antioxidant activity of the extracellular fraction, of the strains FSO1 and L18, and their combination (FSO1/ L18) obtained on MRSm after 7 days of incubation at 30 ${ }^{\circ} \mathrm{C}$, was evaluated by measuring the DPPH (2,2-diphenyl1-picrylhydrazyl) free radical scavenging effect, according to the method of [26], with some modifications. Briefly, $50 \mu \mathrm{l}$ of the sample (extracellular fraction) was added to $1.95 \mathrm{ml}$ of freshly prepared DPPH $(25 \mathrm{mg} / \mathrm{l}$ in methanol). After $40 \mathrm{~min}$ of incubation in dark at room temperature, the absorbance was measured at $517 \mathrm{~nm}$ against a blank, consisting of $200 \mu \mathrm{l}$ of DPPH solution and $100 \mu \mathrm{l}$ of methanol. Ascorbic acid $(0-100 \mu \mathrm{g} / \mathrm{ml})$ was used as control. The antioxidant activity (AA, \%) was calculated using the following equation: AA (\%) = $\left(\left(A_{0}-A_{1}\right) / \mathrm{A}_{0}\right) \times 100$, where $A_{0}$ was the absorbance of the blank, and $A_{1}$ was the absorbance of the sample of extracts and standards. Three replicates were taken for each assay.

\section{$\beta$-Glucosidase production conditions \\ Effect of incubation time}

The in vitro monitoring of $\beta$-glucosidase production was determined by measuring the hydrolysis rate of $\mathrm{p}-\mathrm{NPG}$, to $\beta$-D-glucose and para-nitrophenol, by $\beta$-glucosidase of the fractions $E$ of the strains FSO1, L18 and their combination (FSO1/L18). For this, $10 \mu \mathrm{L}$ of overnight cultures of each strain $(5 \mu \mathrm{L}$ each of each strain when combined, FSO1/L18) were inoculated in $10 \mathrm{~mL}$ of modified MRSm broth, containing oleuropein $(1 \%, \mathrm{w} / \mathrm{v})$ as a sole carbon source. The cultures, made in triplicate, were incubated at $30{ }^{\circ} \mathrm{C}$ from one day to 9 days. Samples were harvested from the cultures and analyzed for their $\beta$-glucosidase activity and biomass content. The $\beta$ glucosidase activity was measured as described above. The biomass was measured by enumeration of L. plantarum FSO1 on MRS agar and C. pelliculosa L18 on Potato Dextrose Agar (PDA). Cycloheximide $(0.01 \%, \mathrm{w} / \mathrm{v})$ was added to MRS to prevent the growth of yeast, while gentamicin $(4 \%, \mathrm{w} / \mathrm{v})$ was added to PDA to prevent the growth of L. plantarum.

\section{Effect of $p H$}

The effect of $\mathrm{pH}$ on the production of $\beta$-glucosidase, by the strains FSO1 and L18 and their combination, was determined by measuring the $\beta$-glucosidase activity of their culture obtained on MRSm broth adjusted to different initial $\mathrm{pHs}(4,5$, and 6), and inoculated with $10 \mu \mathrm{l}$ of overnight cultures of the strains (FSO1, L18, and 
FSO1/L18), as described above. After 7 days of incubation at $30{ }^{\circ} \mathrm{C}$, the $\beta$-glucosidase activity was measured on the extracellular fraction, using the same protocol described above. Two controls were used in this experiment, citrate buffer (50 $\mathrm{mM}$ at $\mathrm{pH} 4.8$ ) as negative control and commercial $\beta$-glucosidase (EC 3.2.1.21, Sigma-Aldrich) as a positive control. All the experiments were performed in triplicate.

\section{Effect of $\mathrm{NaCl}$}

The effect of $\mathrm{NaCl}$ on the production of $\beta$-glucosidase by the strains studied (FSO1, L18, and FSO1/L18) was determined by measuring the $\beta$-glucosidase activity of their cultures obtained on MRSm broth adjusted to different $\mathrm{NaCl}$ concentrations $(0,2,4,6,8$, and $10 \%, \mathrm{w} / \mathrm{v})$, and inoculated with overnight cultures as described above. After 7 days of incubation at $30{ }^{\circ} \mathrm{C}$, the $\beta$ glucosidase activity was measured on the extracellular fraction using the same protocol described above. Two controls were used in this experiment, citrate buffer (50 $\mathrm{mM}$ at $\mathrm{pH} 4.8)$ as negative control and commercial $\beta$ glucosidase (EC 3.2.1.21) as a positive control. All the experiments were performed in triplicate.

\section{Confirmation of enzymatic activity by TLC}

To confirm the biodegradation of oleuropein by the strains, cultures of L. plantarum FSO1, C. pelliculosa L18, and their combination (FSO1/L18) were carried out on MRSm broth. After 7 days of incubation at $30{ }^{\circ} \mathrm{C}$, the phenolic compounds of the microbial cultures were extracted three times with ethyl acetate $(8: 2, \mathrm{v} / \mathrm{v})$. After decantation, the organic phase was harvested and left in the dark for $30 \mathrm{~min}$ in the presence of disodium sulfate, and then dry evaporated at $50{ }^{\circ} \mathrm{C}$. The residue obtained was dissolved in $1 \mathrm{~mL}$ of methanol. The phenolic extracts obtained were dissolved in $1 \mathrm{ml}$ of methanol and then subjected to Silica-gel thin layer chromatography (TLC) (Silica gel/TLC-cards, Fluka-60778) to separate the phenolic compounds resulting from the degradation of oleuropein. The phenolic extracts and the standards (oleuropein and hydroxytyrosol), prepared in methanol, were deposited on the TLC cards using a glass capillary. The eluent used was composed of toluene/methanol/ acetic acid (15/5/0.5) and (15/5/1) [27]. The observation was realized, when the solvent front reached the upper line (about $10 \mathrm{~min}$ ), under UV light at $254 \mathrm{~nm}$ and 365 $\mathrm{nm}$ after drying the plates.

\section{$\beta$-Glucosidase activity conditions Effect of $\mathrm{pH}$}

The $\beta$-glucosidase activity was measured on the extracellular fraction resulting from the optimal conditions of $\beta$ glucosidase production by the strains studied, including $\mathrm{pH}$ (pH5 for FSO1, pH6 for L18 and FSO1/L18), and
$\mathrm{NaCl}$ concentration ( $0 \%$ of $\mathrm{NaCl}$ for all strains). The effect of $\mathrm{pH}$ on $\beta$-glucosidase activity was measured in 50 $\mathrm{mM}$ citrate buffer at $\mathrm{pH}$ values of $(4,5$, and 6$)$, using 5 $\mathrm{mM}$ of $\mathrm{p}$-NPG as substrate. The activity of $\beta$-glucosidase was measured according to the method described above. All the experiments were made in triplicate.

\section{Effect of $\mathrm{NaCl}$}

The effect of $\mathrm{NaCl}$ on the $\beta$-glucosidase activity of the extracellular fraction of the strains cultures obtained on MRSm was measured in the $50 \mathrm{mM}$ citrate buffer (at pH 5 ) at $50{ }^{\circ} \mathrm{C}$ added with different concentrations of $\mathrm{NaCl}$ $(0,2,4,6$, and $8 \%, w / v)$, and using $5 \mathrm{mM}$ of p-NPG as substrate. The activity of the $\beta$-glucosidase was measured as described above. All the experiments were made in triplicate.

\section{Effect of temperature}

The effect of temperature on $\beta$-glucosidase activity of the extracellular fraction of strains cultures obtained on MRSm was measured in $50 \mathrm{mM}$ citrate buffer (at $\mathrm{pH} 5$ ), using the p-NPG $(5 \mathrm{mM})$ as substrate. The mixture was maintained at temperature values of $6,15,25,35,45$, and $50{ }^{\circ} \mathrm{C}$ for $10 \mathrm{~min}$. The residual activity of $\beta$ glucosidase was measured as described above. All the experiments were made in triplicate.

\section{Statistical analysis}

The data obtained from the replicate assays were presented as the means \pm standard deviation. The means were compared, with a significant difference at $p<0.05$, using one-way ANOVA. The results were plotted using Graph Pad Prism, version 8 for Windows, GraphPad Software, San Diego, California, USA.

\section{Results \\ Enzymatic profile and detection of $\beta$-glucosidase}

The semi-quantitative API-ZYM technique was used to determine the presence and the preliminary quantification of the $\beta$-glucosidase enzyme from Lactobacillus plantarum FSO1 and Candida pelliculosa L18. The results obtained indicate that these strains (FSO1 and L18) produce a wide range of enzymes, with different qualitative and quantitative profiles (Table 1). Among these enzymes, $\alpha$ glucosidase and $\beta$-glucosidase are the most highly detected in both strains. The $\alpha$-glucosidase score of the APIZYM scale is $4(30 \mathrm{nmol})$ in both strains, while $\beta$ glucosidase scores are $3(20 \mathrm{nmol})$ and $4(30 \mathrm{nmol})$, respectively in FSO1 and L18. Other enzymes, involved in the catabolism of nutrients, are detected at lower contents, such as Naphthol phosphohydrolase, $\beta$-galactosidase, alkaline and acid phosphatases, esterase (C4), esterase lipase (C8), lipase (C14), leucine arylamidase, valine arylamidase, 
Table 1 Enzymatic activity of oleuropeinolytic strains obtained by API-Zym system

\begin{tabular}{|c|c|c|}
\hline \multirow[t]{2}{*}{ Enzymes } & \multicolumn{2}{|c|}{ Enzymatic activity $(\mathrm{nmol} / 5 \mathrm{~h}$ ) level } \\
\hline & $\begin{array}{l}\text { Lactobacillus } \\
\text { plantarum FSO1 }\end{array}$ & $\begin{array}{l}\text { Candida pelliculosa } \\
\text { L18 }\end{array}$ \\
\hline Control (no substrate) & 0 & 0 \\
\hline Phosphatase alkaline & 2 & 2 \\
\hline Esterase (C4) & 1 & 2 \\
\hline Esterase lipase (C8) & 1 & 1 \\
\hline Lipase (C14) & 1 & 1 \\
\hline Leucine arylamidase & 1 & 0 \\
\hline Valine arylamidase & 1 & 2 \\
\hline Cystine arylamidase & 1 & 2 \\
\hline Trypsin & 1 & 2 \\
\hline a-Chymotrypsin & 0 & 1 \\
\hline Acid phosphatase & 2 & 2 \\
\hline Naphthol phosphohydrolase & 3 & 2 \\
\hline a-Galactosidase & 0 & 0 \\
\hline$\beta$-Galactosidase & 1 & 2 \\
\hline$\beta$-Glucuronidase & 0 & 0 \\
\hline a-Glucosidase & 4 & 4 \\
\hline$\beta$-Glucosidase & 2 & 4 \\
\hline N-Acetyl- $\beta$-glucosaminidase & 2 & 0 \\
\hline a-Mannosidase & 0 & 1 \\
\hline a-Fucosidase & 0 & 1 \\
\hline
\end{tabular}

The scale of the API-Zym test was used for enzymatic quantification, $0=$ no enzyme, $1=5 \mathrm{nmol}, 2=10 \mathrm{nmol}, 3=20 \mathrm{nmol}, 4=30 \mathrm{nmol}$ and $5=40 \mathrm{nmol}$ or more

cystine arylamidase, trypsin, acid phosphatase, $\mathrm{N}$-acetyl- $\beta$ glucosaminidase, $\alpha$-mannosidase, $\alpha$-fucosidase.

\section{Detection of $\beta$-glucosidase}

The $\beta$-glucosidase activity was detected by the hydrolysis of esculin. Both strains (L. plantarum FSO1 and C. pelliculosa L18), as well as commercial $\beta$-glucosidase (positive control), showed hydrolysis of esculin to form a black precipitate, while no color change was observed with distilled water (negative control) (Fig. 1). The hydrolysis of esculin was determined by the observation of a brown-black color, as a result of the reaction of $\mathrm{Fe}^{3+}$ with esculetin, resulting from the hydrolysis of esculin [28].

\section{Induction and localization of $\beta$-glucosidase}

The results of the induction and localization of $\beta$ glucosidase of the studied strains are indicated in Fig. 2. In presence of oleuropein, as a sole carbon source, the $\beta$-glucosidase activity values obtained in the extracellular fraction are $1.32 \mathrm{U} / \mathrm{mL}$ for C. pelliculosa L18 and 0.71 $\mathrm{U} / \mathrm{mL}$ for $L$. plantarum FSO1, while in absence of oleuropein, a very low activity was detected in all fractions (extracellular: $E$, intracellular: $I$, and cell wall: $M$ ) of both strains.

\section{SDS-PAGE}

The results of the enzyme profile of the strains FSO1 and L18, obtained by the SDS-PAGE technique are reported in Fig. 3. Both strains, L. plantarum FSO1 and C. pelliculosa L18 showed a band of molecular weight of 60 $\mathrm{kDa}$, corresponding to the $\beta$-glucosidase enzyme (EC 3.2.1.21) used as standard.

\section{Confirmation of enzymatic activity by TLC}

The phenolic compounds extracted from the microbial cultures of (FSO1, L18, and FSO1/L18), obtained after 7 days of incubation at $30{ }^{\circ} \mathrm{C}$ on MRSm (containing oleuropein as a sole carbon source), were subjected to thinlayer chromatographic (TLC) separation. The results obtained are reported in Fig. 4. Oleuropein (OLP) and hydroxytyrosol (HT) were used as standards, and the separation system was toluene/methanol/acetic acid (15/ $5 / 0.5)$.

The results indicated the separation of extracted phenolic compounds into several components (spots). The retention factor (Rf) values obtained for the OLP and HT (standards) were 0.16 and 0.37 , respectively. All the components obtained showed absorbance at UV 365 $\mathrm{nm}$. The strains FSO1 and L18 demonstrated an absence of OLP spot, and the appearance of HT and 2 other components ( $\mathrm{C} 1$ and $\mathrm{C} 2)$, with $\mathrm{Rf}$ values of $0.37,0.48$, and 0.54 , respectively. These results indicate the production of $\beta$-glucosidase and esterase by $L$. plantarum FSO1 and C. pelliculosa L18, and it can also be due to the acidification of the medium resulting from the fermentation of glucose released from the degradation of oleuropein by $\beta$-glucosidase [29], leading to the elimination of oleuropein and accumulation of hydroxytyrosol.

\section{Antioxidant activity}

The antioxidant activity (AA) values, of the culture of the strains (FSO1, L18, and FSO1/L18) measured by DPPH scavenging activity, are reported in Fig. 5. The values obtained were $97.81 \%$ for $L$. plantarum FSO1, 94.17\% for C. pelliculosa L18, and 93.62\% for their combination (FSO1/L18); while ascorbic acid showed an AA value of $75.28 \%$. The AA values of the strains (FSO1, L18, and FSO1/L18) were significantly $(p<0.05)$ higher than the one obtained for ascorbic acid.

\section{Production of $\beta$-glucosidase \\ Effect of incubation time}

The $\beta$-glucosidase ( $\beta$-Glu) activity values of FSO1 and L18 and their combination (FSO1/L18), obtained during 9 days of culture at $30{ }^{\circ} \mathrm{C}$, are reported in Fig. 6. Both 


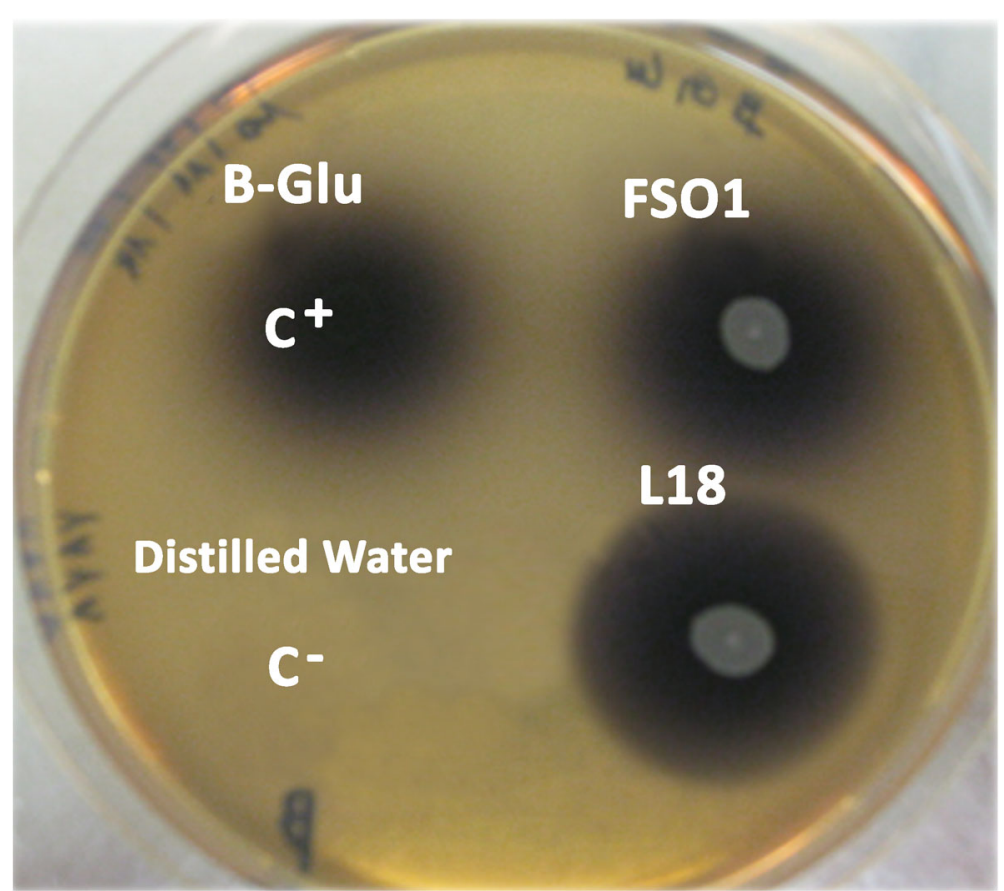

Fig. 1 Hydrolysis of esculin obtained on esculin-based medium after 2 days of incubation at $30^{\circ} \mathrm{C}$ of L. plantarum (FSO1) and C. pelliculosa (L18) (legend: $C^{+}$(B-Glu), commercial enzyme ( $\beta$-glucosidase EC 3.2.1.21); C: distilled water)

strains and their combination showed an increase in their $\beta$-glucosidase activity values until day 7 of culture and decreased thereafter. The maxima of $\beta$-glucosidase activity values obtained were $0.77,1.47$, and $0.96 \mathrm{U} / \mathrm{mL}$, respectively for L. plantarum FSO1, C. pelliculosa L18, and their combination FSO1/L18. The yeast strain L18 displayed a $\beta$-glucosidase activity twice that of $L$. plantarum FSO1.

The combination FSO1/L18 showed $\beta$-glucosidase activity value significantly $(p<0.05)$ lower than that obtained with L18 alone, and significantly $(p<0.05)$ higher than that obtained with L. plantarum FSO1 alone. This may be due mainly to the decrease of $\mathrm{pH}$ to a lower value than the optimum $\mathrm{pH}$ of $\beta$-glucosidase, due to organic acids production by L. plantarum FSO1.

The biomass values of FSO1 and L18 obtained in their pure or mixed culture are reported in Fig. 7. For each strain (FSO1 or L18), the biomass values obtained in pure culture are lower than those obtained in mixed cultures.

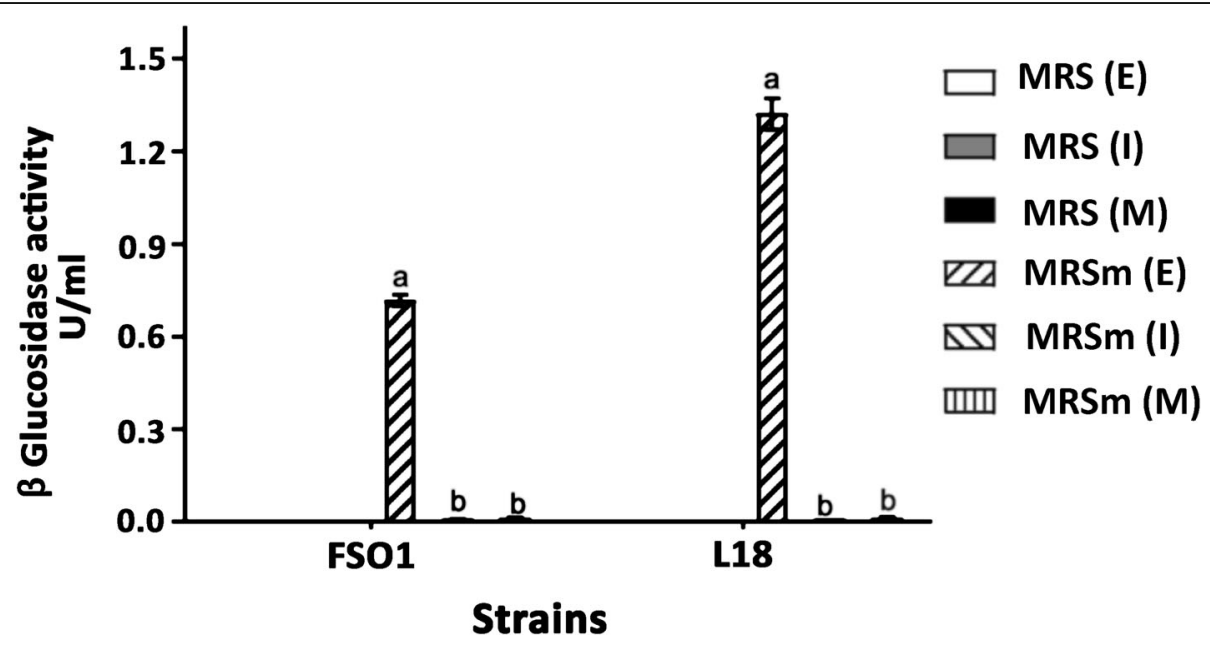

Fig. $2 \beta$-Glucosidase activity of L. plantarum FSO1 and C. pelliculosa L18 obtained after 7 days of culture at $30^{\circ} \mathrm{C}$ on MRS and modified MRS (MRSm) containing oleuropein (1\%) as a sole carbon source. (Legend: $\beta$-glucosidase activity in (E): extracellular; (): intracellular and (M): parietal fractions) 


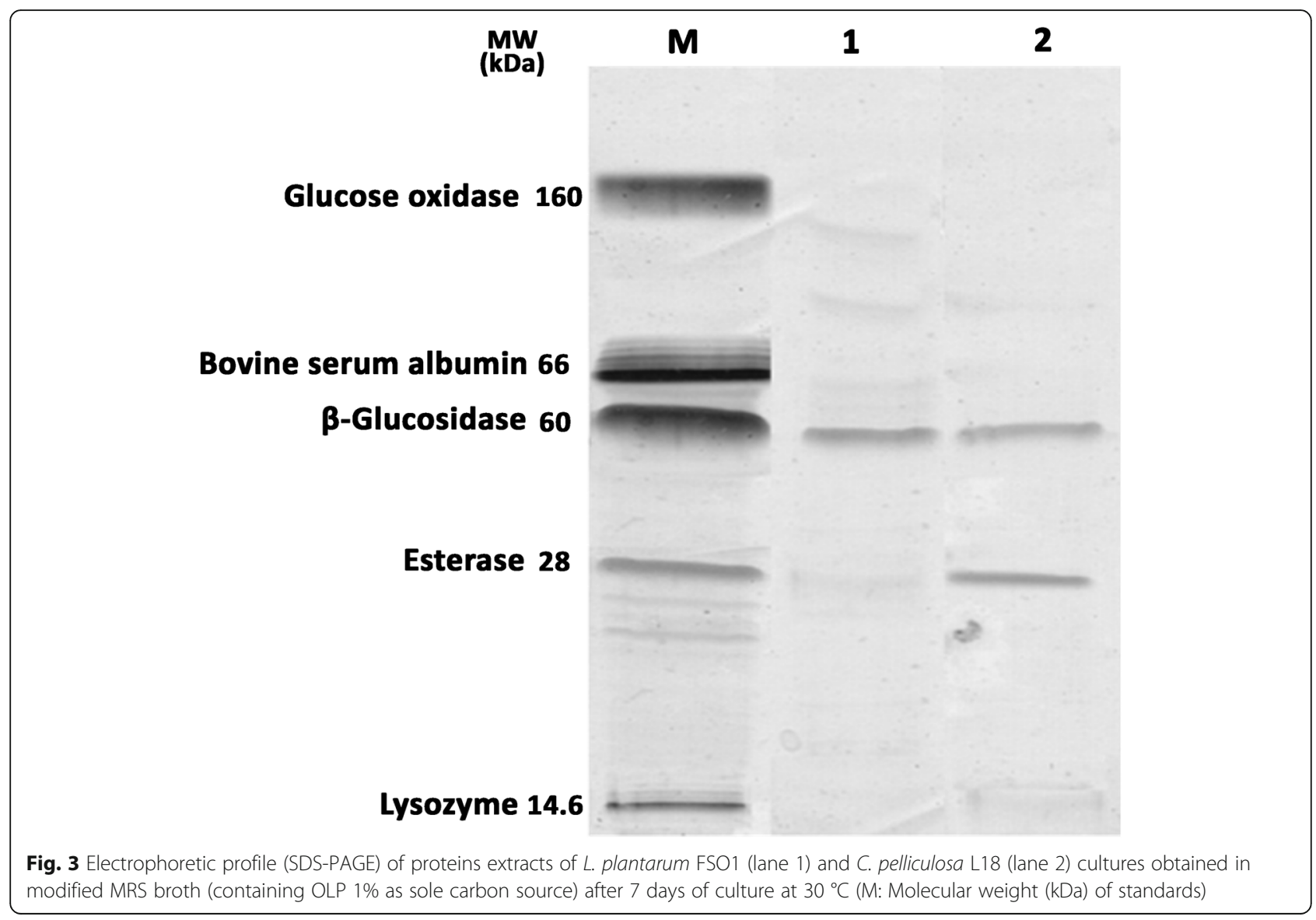

\section{Effect of $\mathrm{pH}$ on $\beta$-glucosidase production}

The $\beta$-glucosidase activity values obtained for the strains (FSO1, L18, and FSO1/L18) after 7 days of culture at 30 ${ }^{\circ} \mathrm{C}$ on MRSm (MRS medium containing oleuropein (1\%) as sole carbon source) adjusted to different initial $\mathrm{pH}(4$, 5, and 6) are displayed in Fig. 8. L. plantarum FSO1 showed optimum production of $\beta$-glucosidase $(0.91 \mathrm{U} /$ $\mathrm{mL})$ at $\mathrm{pH} 5$, while the values obtained at $\mathrm{pH} 4(0.63 \mathrm{U} /$ $\mathrm{mL})$ and $\mathrm{pH} 6(0.79 \mathrm{U} / \mathrm{mL})$ were significantly $(p<0.05)$ lower.

\section{Effect of $\mathrm{NaCl}$ on $\beta$-glucosidase production}

The effect of $\mathrm{NaCl}(0,2,4,6,8$, and $10 \%, w / v)$ on the production of $\beta$-glucosidase, by the strains (FSO1, L18, and FSO1/L18) on MRSm medium (containing oleuropein $1 \%$ as sole carbon source), is reported in Fig. 9. The maximum $\beta$-glucosidase activity was obtained in the absence of $\mathrm{NaCl}(0 \%)$, and the values obtained were 0.76 $\mathrm{U} / \mathrm{mL}, 1.02 \mathrm{U} / \mathrm{mL}$, and $0.72 \mathrm{U} / \mathrm{mL}$, respectively for $L$. plantarum FSO1, C. pelliculosa L18, and their combination FSO1/L18. The production of $\beta$-glucosidase decreased, with the increase of $\mathrm{NaCl}$ to reach minimum activity values of $0.51 \mathrm{U} / \mathrm{mL}, 0.61 \mathrm{U} / \mathrm{mL}$, and $0.32 \mathrm{U} /$ $\mathrm{mL}$, obtained at $10 \% \mathrm{NaCl}$ for FSO1, L18, and FSO1/ L18, respectively.

\section{Activity of $\beta$-glucosidase}

Effect of $\mathrm{pH}$ on $\beta$-glucosidase activity

The effect of $\mathrm{pH}$ on the $\beta$-glucosidase activity of the strains FSO1, L18, and FSO1/L18 is reported in Fig. 10. The optimum $\beta$-glucosidase residual activity value was obtained at $\mathrm{pH} 5$ for all strains, with activity values of $0.79 \mathrm{U} / \mathrm{mL}$ for L. plantarum FSO1, $1 \mathrm{U} / \mathrm{mL}$ for C. pelliculosa L18, and $0.88 \mathrm{U} / \mathrm{mL}$ for their combination (FSO1/L18). The optimum residual activity values of L18 and FSO/L18 are higher than that of L. plantarum FSO1.

\section{Effect of $\mathrm{NaCl}$ on $\beta$-glucosidase activity}

The effect of $\mathrm{NaCl}$ on the $\beta$-glucosidase activity of the strains (FSO1, L18, and FSO1/L18) is reported in Fig. 11. The $\beta$-glucosidase activity values of all strains increased slightly from 0 to $4 \%$, and highly from 4 to $8 \%$. The maximum of $\beta$-glucosidase residual activity values was obtained at $8 \%(\mathrm{w} / \mathrm{v}) \mathrm{NaCl}$, with activity values of $0.75 \mathrm{U} /$ $\mathrm{mL}$ for $L$. plantarum FSO1, 1.04 U / $\mathrm{mL}$ for C. pelliculosa $\mathrm{L} 18$, and $0.73 \mathrm{U} / \mathrm{mL}$ for their combination (FSO1/L18). These residual activity values are significantly different $(p$ $<0.05$ ) between pure strains FSO1, L18 and FSO1/L18, and indicate the highest activity of C. pelliculosa L18, 


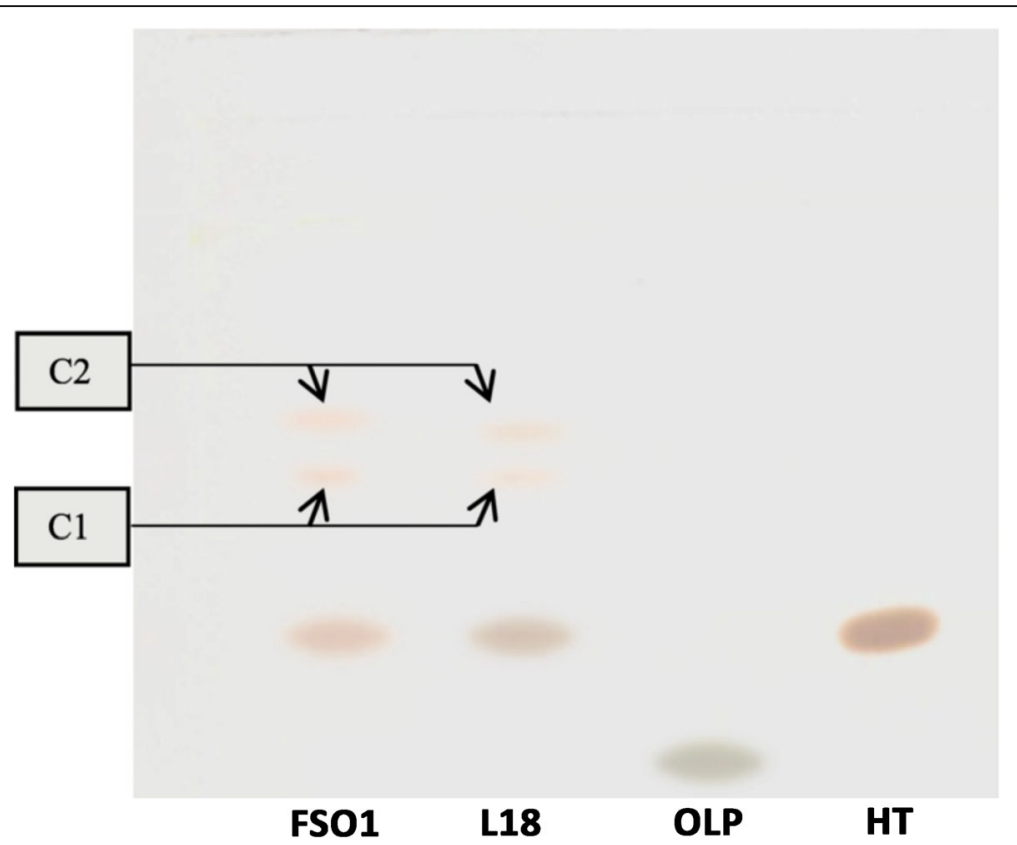

Fig. 4 TLC of the methanolic fraction of oleuropeinolytic strains extracts and standards developed by toluene/methanol/acetic acid system (15/5/ 0.5) and observed under white light. (Legend: FSO1: L. plantarum FSO1, L18: C. pelliculosa L18, OLP: oleuropein, HT: hydroxytyrosol)

followed by the combination FSO1/L18 and finally by $L$. plantarum FSO1.

\section{Effect of temperature on $\beta$-glucosidase activity}

The effect of temperature on the activity of $\beta$ glucosidase of the strains (FSO1, L18, and FSO1/L18) is reported in Fig. 12. The optimum $\beta$-glucosidase activity of L18 and FSO1/L18 was obtained at $35{ }^{\circ} \mathrm{C}$, with maximum activity values of 1.48 and $1.17 \mathrm{U} / \mathrm{mL}$, respectively; While for $\mathrm{FSO} 1$, the optimum was obtained at $45^{\circ} \mathrm{C}$, with a residual activity value of $1.46 \mathrm{U} / \mathrm{mL}$.

\section{Discussion}

Both strains, L. plantarum FSO1 and C. pelliculosa L18 showed hydrolysis of esculin by producing the $\beta$ glucosidase enzyme. Previous studies reported the $\beta$ glucosidase activity in lactic acid bacterial strains [15, 30-33], and yeast strains [34, 35], isolated from olive brine.

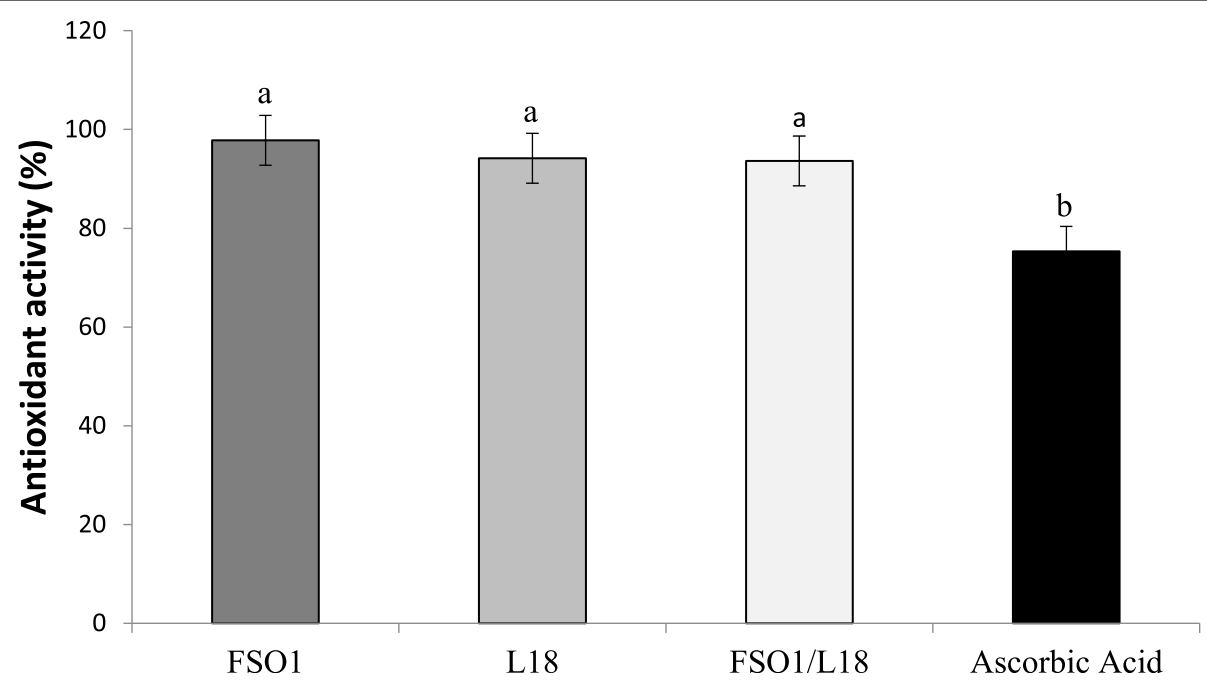

Fig. 5 Free radical scavenging activity (\%) of cultures of L. plantarum FSO1, C. pelliculosa L18, and their combination FSO1/L18 obtained after 7 days of incubation at $30^{\circ} \mathrm{C}$ in MRSm containing oleuropein as a sole carbon source 


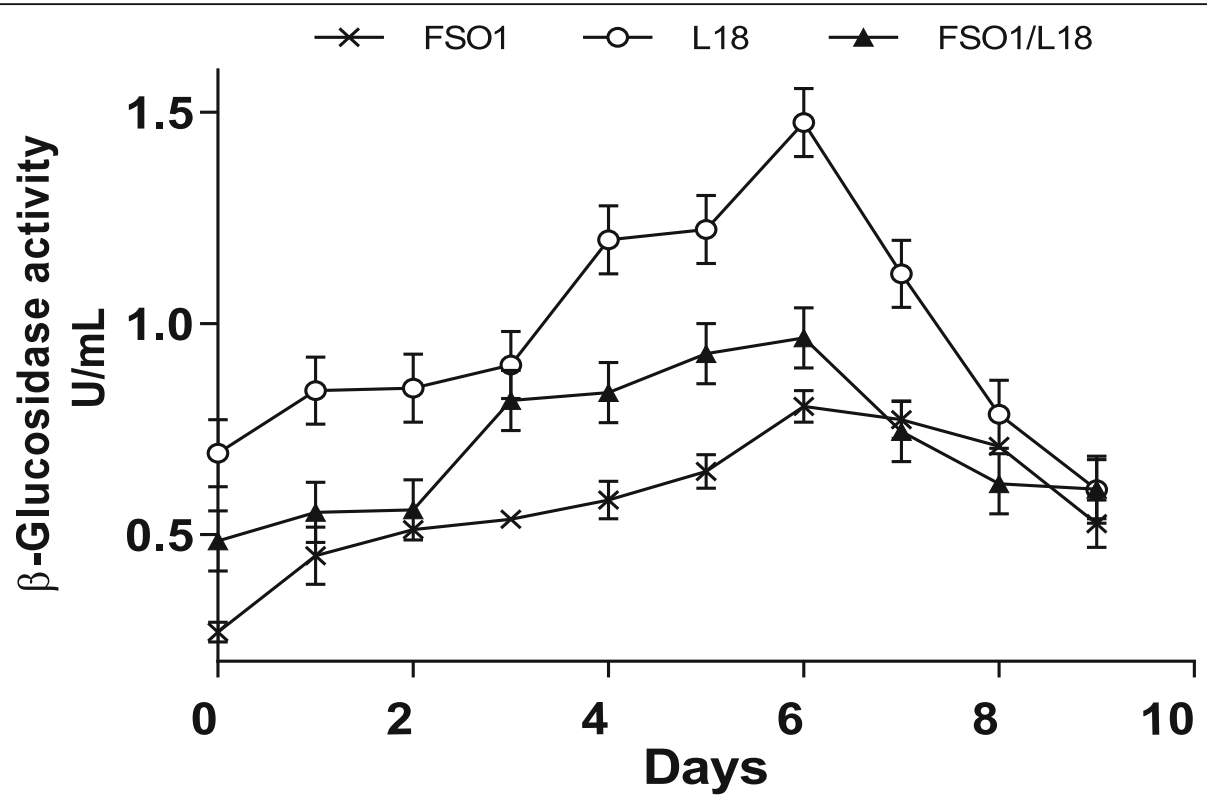

Fig. $6 \beta$-Glucosidase activity of pure (FSO1, L18) and combined (FSO1/L18) cultures during 9 days of incubation at $30^{\circ} \mathrm{C}$ in modified MRS broth containing oleuropein (1\%) as a sole carbon source. (Legend: FSO1: L. plantarum, L18: C. pelliculosa)

High levels of $\beta$-glucosidase activity were detected in both strains (L. plantarum FSO1 and C. pelliculosa L18). This may be due to their natural selection in the spontaneous fermentation process of non-debittered green olive brine. The traditional fermentation process of nondebittered green olive is characterized by high contents of phenolic compounds (oleuropein) and $\mathrm{NaCl}(0-12 \%)$ and lower nutrients contents $[17,36]$. The microbial strains, involved in this fermentation process, should have an important and wide enzymatic profile, mainly $\beta$ glucosidase, to overcome the stress factors of this extreme environment. The $\beta$-glucosidase activity is frequent in lactic acid bacterial strains isolated from the traditional non-alkali-treated green olive fermentation process [15].

The results indicate that the production of $\beta$ glucosidase by these strains is extracellular and induced by oleuropein. This result is in agreement with that found by Sestelo, Poza [10]. Other studies reported, however, high $\beta$-glucosidase activity in intracellular fractions of Lactobacillus and yeast [13, 37, 38]. The MW $(60 \mathrm{kD})$ of the extracellular $\beta$-glucosidase we obtained in these strains (FSO1 and L18), is comparable to that reported for extracellular $\beta$-glucosidase $[39,40]$, but lower

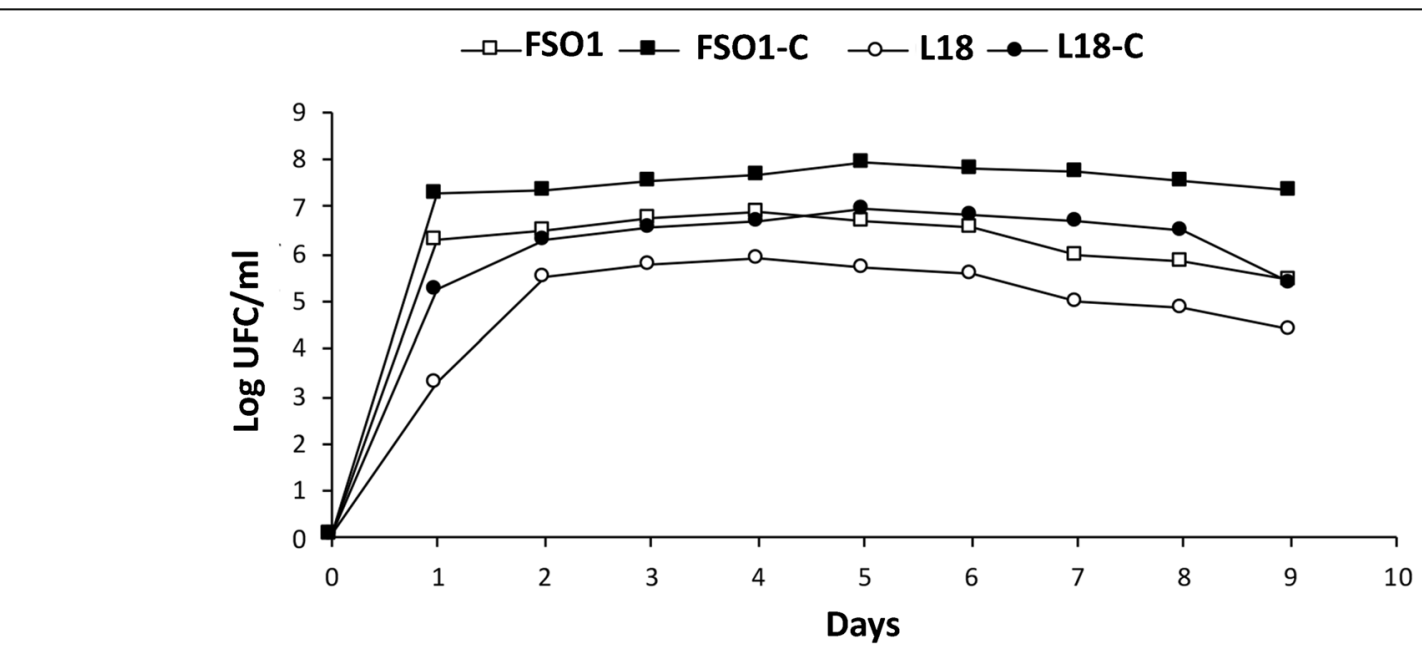

Fig. 7 Evolution of biomass growth of FSO1 and L18 in pure cultures and combined culture (FSO1-C, L18-C) in modified MRS medium (Legend: FSO1: L. plantarum, L18: C. pelliculosa, FSO1-C: FSO1 in FSO1/L18, L18-C: L18 in FSO1/L18) 


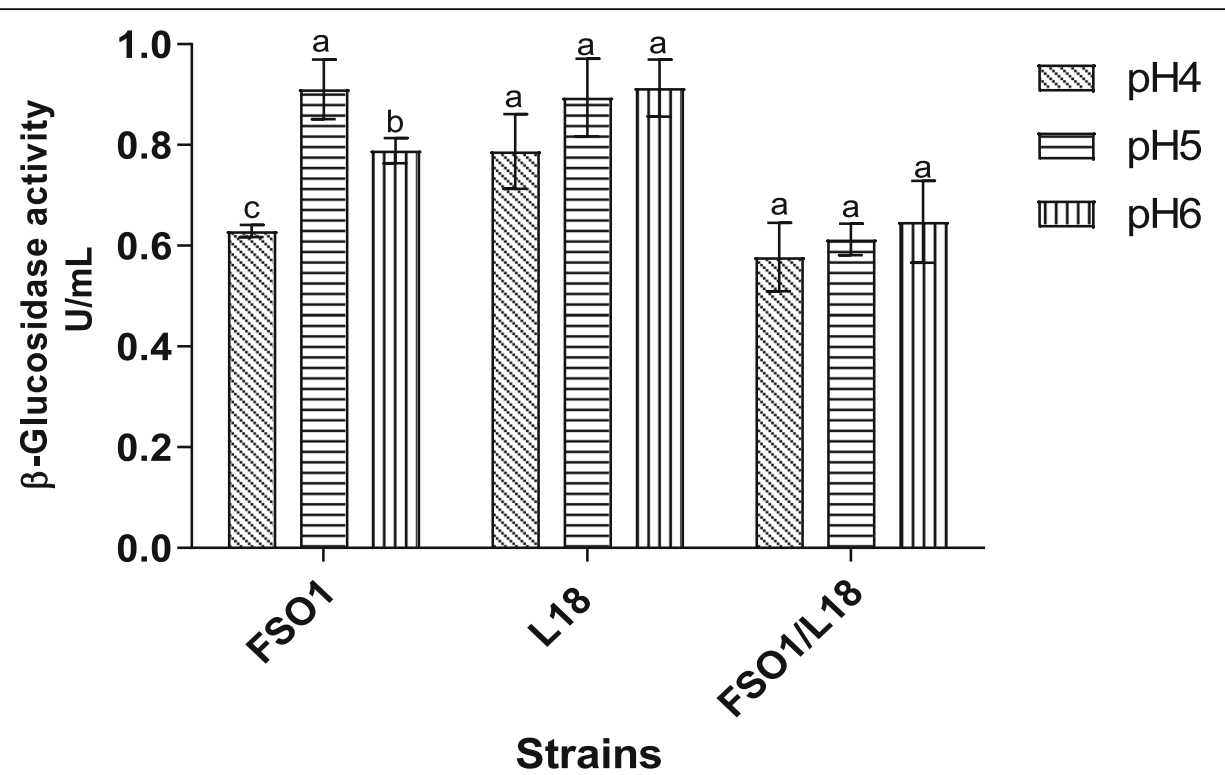

Fig. 8 -Glucosidase activity of strains (FSO1, L18, and FSO1/L18) cultures obtained after 7 days of incubation at $30^{\circ} \mathrm{C}$ in MRSm adjusted to different initial pH (4, 5 and 6). (Legend: MRSm: MRS containing oleuropein (1\%) as a sole carbon source, FSO1: L. plantarum FSO1, L18: C. pelliculosa L18, FSO1/L18: combination of FSO1 and L18)

than that reported for intracellular $\beta$-glucosidase [37, 38]. The esterase enzyme of MW $28 \mathrm{kDa}$, obtained in $C$. pelliculosa L18, is comparable to that obtained by Esteban-Torres, Reveron [41]. The esterase was not detected in L. plantarum FSO1, which may be due to its lower content.

The degradation of OLP by FSO1 and L18 strains led to the appearance of HT and 2 other components $(\mathrm{C} 1$ and $\mathrm{C} 2)$, revealed by TLC. These compounds ( $\mathrm{C} 1$ and C2) may correspond to intermediate phenolic compounds, other than HT, such as hydroxytyrosol glucoside, tyrosol, 3,4-dihydroxy phenylacetic acid, or elenolic acid [42]. HT was reported as the final product of oleuropein biodegradation [1]. It was demonstrated that the biodegradation of oleuropein by $\beta$-glucosidase results in glucose and aglycone [3,39], and thereby, the aglycone

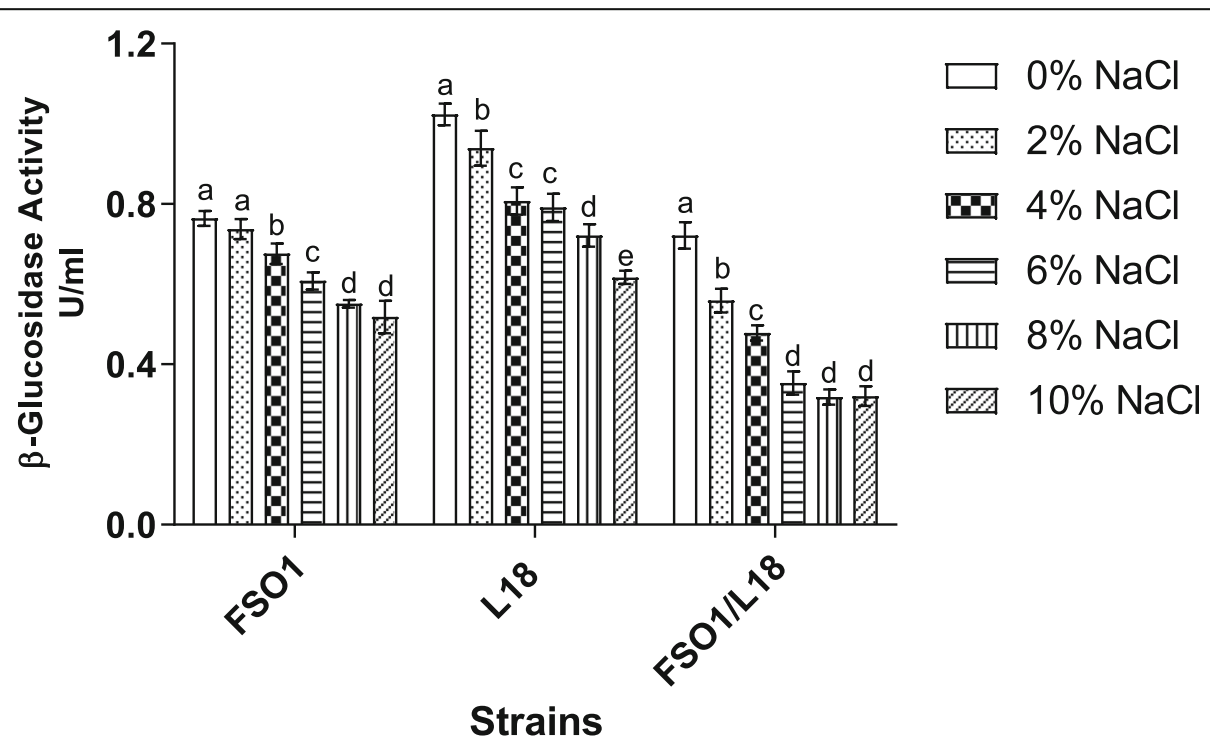

Fig. $9 \beta$-Glucosidase activity produced by strains FSO1, L18 and FSO1/L18 after 7 days of culture at $30{ }^{\circ} \mathrm{C}$ in MRSm adjusted to different initial $\mathrm{NaCl}$ concentrations (Legend: MRSm: MRS containing oleuropein (1\%) as a sole carbon source, FSO1: L. plantarum FSO1, L18: C. pelliculosa L18, FSO1/L18: combination of FSO1 and L18) 


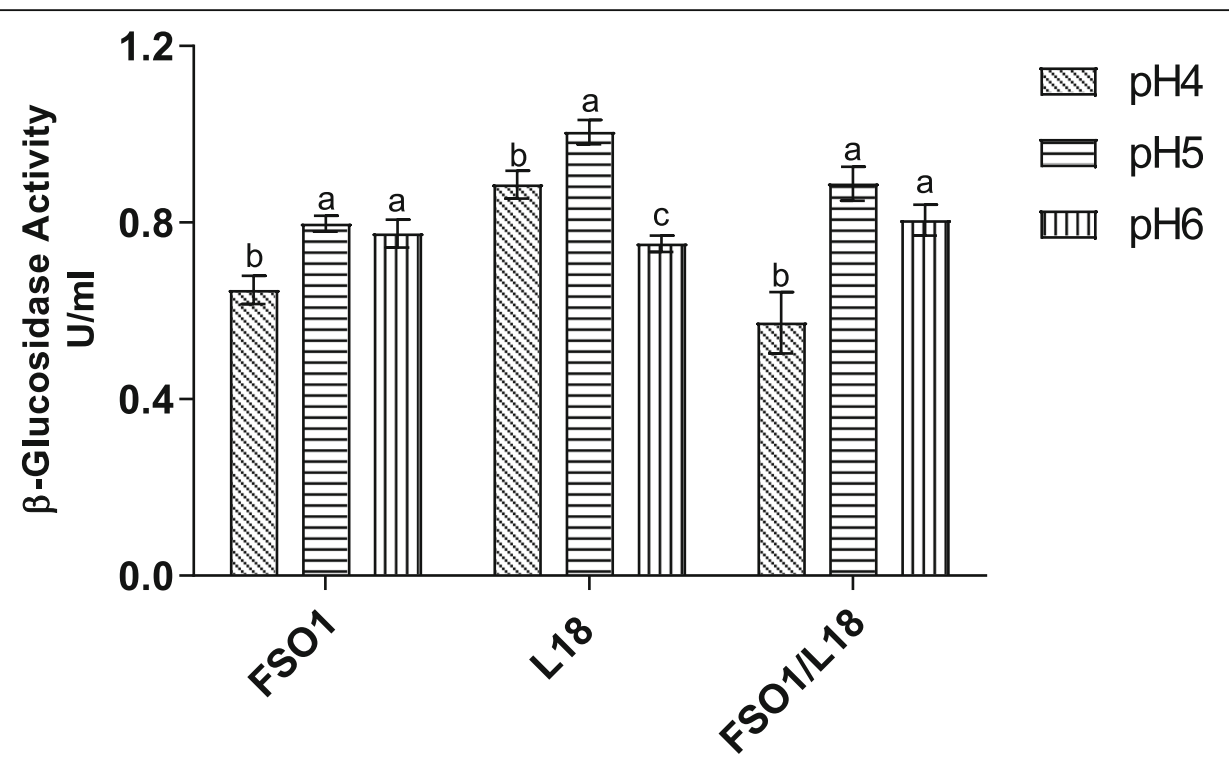

Fig. 10 Residual activity of $\beta$-glucosidase after 7 days of cultures at $30^{\circ} \mathrm{C}$ for pure (FSO1, L18) and combined (FSO1/L18) cultures in modified MRS broth containing oleuropein (1\%) as a sole carbon source at different final pH. (Legend: FSO1: L. plantarum, L18: C. pelliculosa).

is degraded by esterase to simpler phenolic compounds, namely hydroxytyrosol and elenolic acid $[1,4]$.

The higher AA values, obtained with culture extracts of the strains (FSO1, L18, and FSO1/L18), may be due to oleuropein and its hydrolysis products, particularly hydroxytyrosol, which is highly desired in foods [43, 44]. The culture extracts of the strains demonstrated the biodegradation of oleuropein and accumulation of hydroxytyrosol and other phenolic compounds, leading to antioxidant activity values significantly higher than that of ascorbic acid.
The enhancement of biomass growth, observed in a mixed culture of $L$. plantarum FSO1 and C. pelliculosa L18, may be due to mutual metabolic nutrients exchange between these strains. Metabolic cross-feeding interactions were demonstrated in microbial communities of yeasts and Lactobacillus, particularly in the nutrientlimited environment $[45,46]$.

The lowest $\beta$-glucosidase activity value observed at $\mathrm{pH}$ 4 , may be due to the reduction of biomass growth and to $\mathrm{pH}$ change far from the optimum $\mathrm{pH}$ of the enzyme. The reduction of biomass growth with a decrease of $\mathrm{pH}$

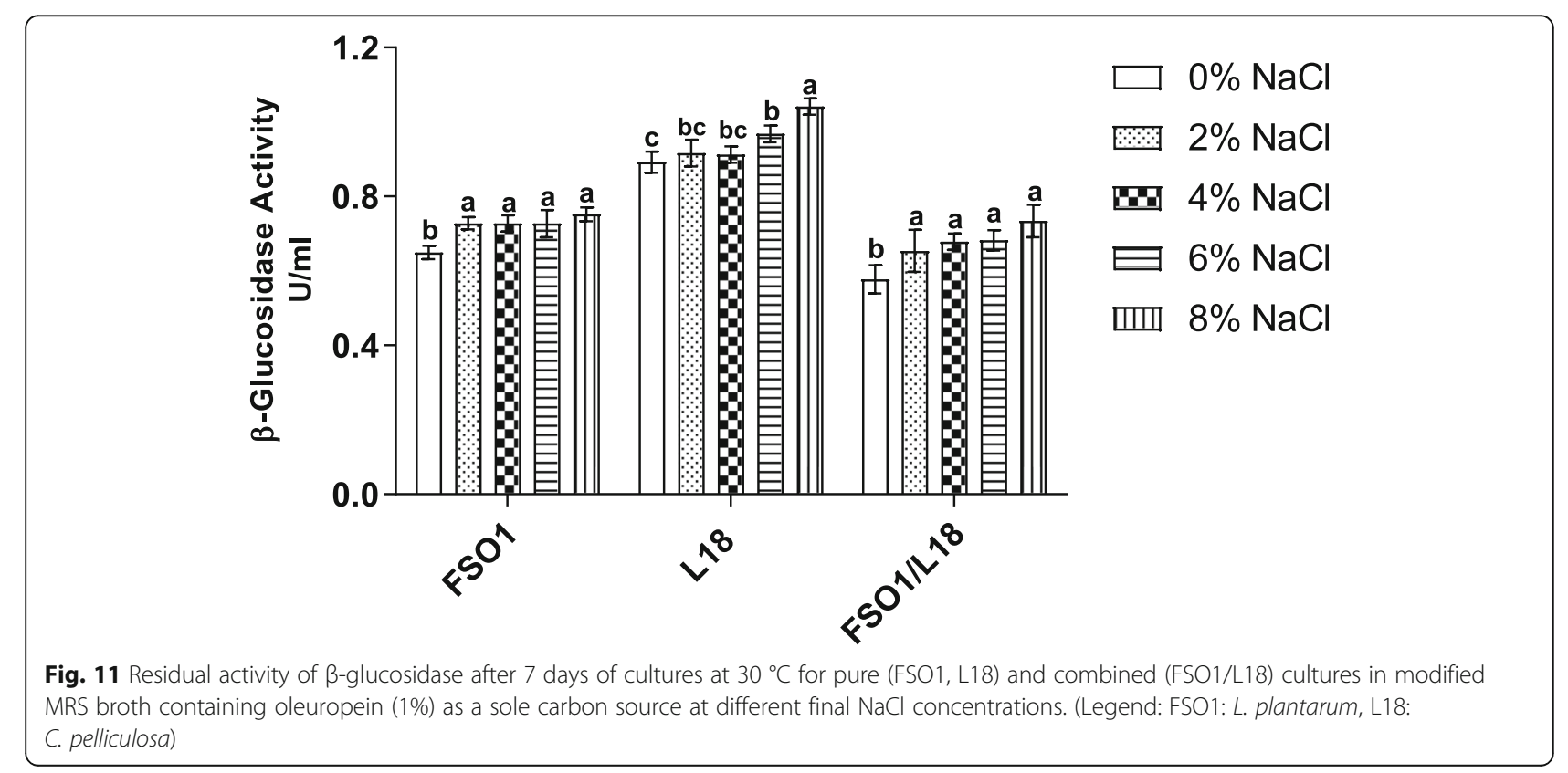




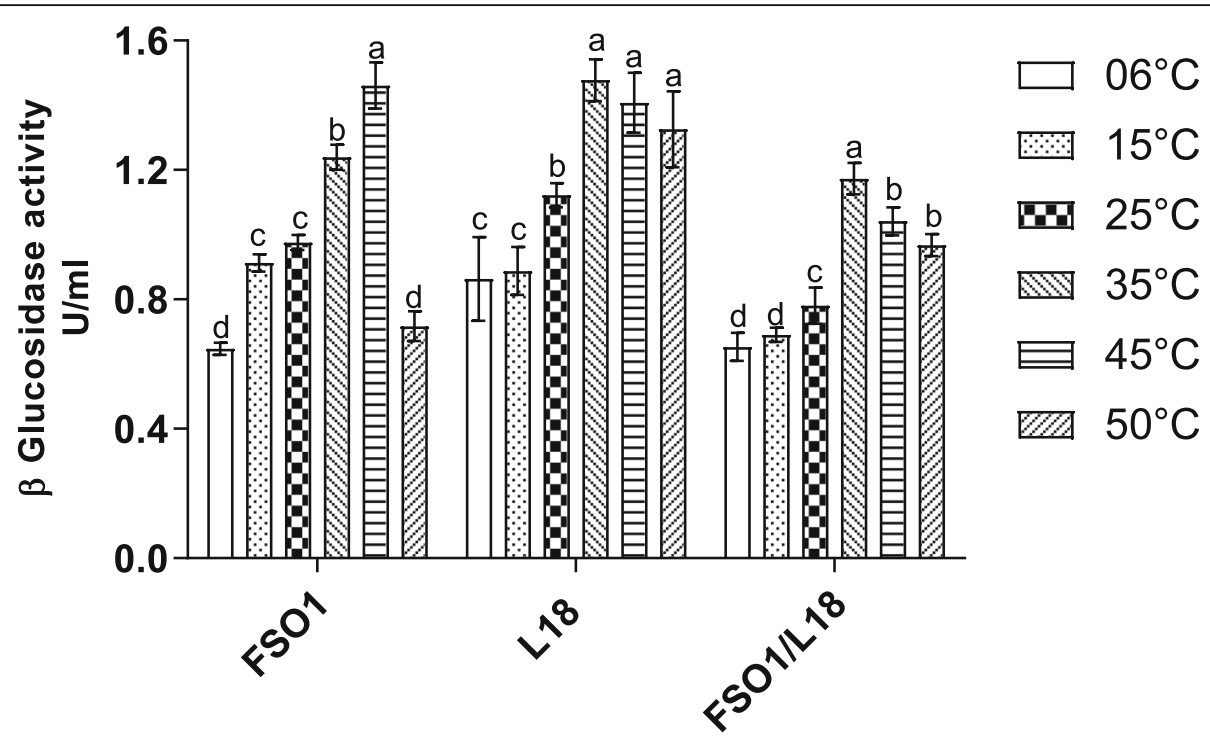

Fig. 12 Residual activity of $\beta$-glucosidase after 7 days of cultures at $30{ }^{\circ} \mathrm{C}$ for pure (FSO1, L18) and combined (FSO1/L18) cultures in modified MRS broth containing oleuropein (1\%) as a sole carbon source at different final temperatures. (Legend: FSO1: L. plantarum, L18: C. pelliculosa)

was demonstrated in Lactobacillus strains isolated from olive brine [11]. It was reported that the $\mathrm{pH}$ range affects the production of $\beta$-glucosidase in Lactobacillus plantarum [47]. For C. pelliculosa L18, the $\beta$-glucosidase activity value increased, not significantly $(p<0.05)$, with an increase of $\mathrm{pH}$ to a maximum activity value of 0.91 $\mathrm{U} / \mathrm{mL}$ obtained at $\mathrm{pH} 6$. These results indicate the wide $\mathrm{pH}$ range of the production of $\beta$-glucosidase in C. pelliculosa L18. The optimum $\mathrm{pH}$ of $\beta$-glucosidase production reported by other researchers for yeasts ranged between 5 and $6.5[48,49]$.

The combination FSO1/L18 produced $\beta$-glucosidase activity values lower than those obtained with each strain alone. The $\beta$-glucosidase activity value increased, not significantly $(p<0.05)$, with an increase of $\mathrm{pH}$ to reach the maximum activity of $0.64 \mathrm{U} / \mathrm{mL}$ obtained at $\mathrm{pH}$ 6. These findings may lead us to conclude that the production of $\beta$ glucosidase is dependent on the initial $\mathrm{pH}$ for L. plantarum FSO1, but not for C. pelliculosa L18.

The production of $\beta$-glucosidase is limited with the increase in $\mathrm{NaCl}$ concentration. This result confirms the hypothesis of Gouripur and Kaliwal [47]. The reduction of $\beta$-glucosidase production may be due to the inhibition of biomass growth caused by the increase of the osmotic pressure of $\mathrm{NaCl}$.

The hydrolytic activity of the enzyme has optimum $\mathrm{pH}$ of 5 , which is similar to that of many $\beta$-glucosidases isolated from the Plumeria obtusa (white frangipani) flower [40, 50], and lower than the optimum pH (7.5) obtained for Lactobacillus isolated from dairy products [51]. The enzyme retained $75 \%$ relative activity in the $\mathrm{pH}$ range of 4.5-6.5 [40].

The $\beta$-glucosidase activity increased with the increase of $\mathrm{NaCl}$ concentration, particularly from 4 to $8 \%$. This result is in agreement with the previous work of Restuccia, Muccilli [52]. This stimulation of $\beta$-glucosidase by $\mathrm{NaCl}$ may be due to the increase of the ionization of the reactional solution of the enzyme [53-55].

The optimum temperature $\left(45^{\circ} \mathrm{C}\right)$ is higher than that obtained $\left(30^{\circ} \mathrm{C}\right)$ for $L$. casei and L. rhamnosus isolated from dairy products by Yuksekdag, Cinar Acar [51]. The $\beta$-glucosidase activity value of FSO1 decreased drastically at $50{ }^{\circ} \mathrm{C}$. This result is in agreement with the previous result of Restuccia, Muccilli [52].

\section{Conclusions}

The present study was focused on the characterization of $\beta$-glucosidase of the strains L. plantarum FSO1 and C. pelliculosa L18, isolated from traditional fermented green olive. The strains studied showed extracellular and induced production of $\beta$-glucosidase, with an MW of 60 $\mathrm{kD}$. The production of $\beta$-glucosidase was higher in $C$. pelliculosa L18 than L. plantarum FSO1, while intermediate activity values were obtained with their combination (FSO1/L18). The maximum activity value of all strains was obtained after 6 days of culture and decreased thereafter. The production of $\beta$-glucosidase was optimal at pH 5 and $30{ }^{\circ} \mathrm{C}$ for L. plantarum and $\mathrm{pH} 6$ and $30{ }^{\circ} \mathrm{C}$ for $C$. pelliculosa L18. The activity of the enzyme was optimal at pH 5 and $45^{\circ} \mathrm{C}$ for L. plantarum FSO1, and at pH 5 and $35{ }^{\circ} \mathrm{C}$ for C. pelliculosa L18. The increase of $\mathrm{NaCl}$ concentration reduced the production of $\beta$-glucosidase by the strains, while their enzyme activity increased. The strains L. plantarum FSO1 and C. pelliculosa L18 and/or their enzyme extract showed promising traits for their application in the biological processing of table olives. 


\section{Abbreviations}

\%: Percentage; AA: antioxidant activity; ANOVA: Analysis of variance; C: Candida; ${ }^{\circ} \mathrm{C}$ : Degree Celsius; CNRST: Centre National pour la Recherche Scientifique et Technique; DPPH: 2;2-Diphenyl-1-picrylhydrazyl; g: Gram; HT: Hydroxytyrosol; kDa: Kilodalton; L: Lactobacillus; I: Liter; ml: Milliliter; M: Molar; mM: Millimolar; MRS: De Man Rogosa and Sharp; MRSm: Modified De Man Rogosa and Sharp; NaCl: Sodium chloride; OLP: Oleuropein; pH: Hydrogen potential; p-NP: Para-nitrophenol; p-NPG: Para-nitrophenyl $\beta-D-$ glucopyranoside; Rf: Frontal ratio; SDS: Sodium dodecyl sulfate; SDSPAGE: Sodium dodecyl sulfate-polyacrylamide gel electrophoresis; TLC: Thinlayer chromatography; U: International unit; UV: Ultraviolet; $\mu \mathrm{g}$ : Microgram; $\mu$ l: Microliter; v/v: Volume per volume; w/v: Weight per volume

\section{Acknowledgements}

The authors would like to express their gratitude to the Ministry of Higher Education of Morocco under contracts CNRST-PPR/19/2015 and Tunisian cooperation (17TM06) for their support. Special thanks are due to Dr. Meryam LAMSISSI for proofreading the English editing of the manuscript.

\section{Authors' contributions}

AA selected the scope of the work and supervised the Lab work. YR, HA, RB, $\mathrm{IH}, \mathrm{SG}$, and $\mathrm{ZL}$ conducted the experiments. AA, RBS, NG, ES, and YR wrote the manuscript. All authors read and approved the manuscript.

\section{Funding}

Not applicable

\section{Availability of data and materials}

All data generated or analyzed during this study are included in this article.

\section{Declarations}

\section{Ethics approval and consent to participate}

This article does not contain any studies with human participants or animals performed by any of the authors.

\section{Consent for publication}

Not applicable

\section{Competing interests}

The authors declare that they have no competing interests.

\section{Author details}

${ }^{1}$ Laboratory of Bioresources, Biotechnology, Ethnopharmacology and Health, Faculty of Sciences, Mohammed Premier University, BP 717, Oujda, Morocco. ${ }^{2}$ Laboratory of Microorganisms and Biomolecules, Centre of Biotechnology of Sfax, BP: 1177, 3018 Sfax, Tunisia.

\section{Received: 16 October 2020 Accepted: 21 July 2021}

\section{Published online: 09 August 2021}

\section{References}

1. Charoenprasert S, Mitchell A (2012) Factors influencing phenolic compounds in table olives (Olea europaea). J Agric Food Chem 60(29):70817095. https://doi.org/10.1021/jf3017699

2. Rokni Y, Abouloifa H, Bellaouchi R, Gaamouche S, Mchiouer K, Hasnaoui I, Lamzira Z, Ghabbour N, Asehraou A (2017) Technological process of fermented olive. Arab J Chem Environ Res 04:63-91

3. Limiroli R, Consonni R, Ottolina G, Marsilio V, Bianchi G, Zetta L (1995) $1 \mathrm{H}$ and 13 C NMR characterization of new oleuropein aglycones. J Chem Soc. Perkin Trans 1. https://doi.org/10.1039/P199500015191519-1523, https://doi. org/10.1039/P19950001519

4. Segovia-Bravo KA, Jarén-Galán M, García-García P, Garrido-Fernández A (2009) Browning reactions in olives: Mechanism and polyphenols involved. Food Chem 114(4):1380-1385. https://doi.org/10.1016/j. foodchem.2008.11.017

5. Soler-Rivas C, García-Rosado A, Polonia I, Junca-Blanch G, Marín FR, Wichers HJ (2006) Microbiological effects of olive mill waste addition to substrates for Pleurotus pulmonarius cultivation. Int Biodeterior Biodegradation 57(1): 37-44. https://doi.org/10.1016/j.ibiod.2005.10.007
6. Ghabbour N, Rokni Y, Abouloifa H, Bellaouchi R, Chihib N-E, Salah RB, Lamzira Z, Saalaoui E, Asehraou A (2020) In vitro biodegradation of oleuropein by lactobacillus plantarum FSO 175 in stress conditions $(\mathrm{pH}, \mathrm{NaCl}$ and glucose). J Microbiol Biotechnol Food Sci 9(4):769-773. https://doi.org/1 0.15414/jmbfs.2020.9.4.769-773

7. Lombard V, Ramulu HG, Drula E, Coutinho PM, Henrissat B (2014) The carbohydrate-active enzymes database (CAZy) in 2013. Nucleic Acids Res 42(D1):D490-D495. https://doi.org/10.1093/nar/gkt1178

8. Verdoucq L, Czjzek M, Moriniere J, Bevan DR, Esen A (2003) Mutational and structural analysis of aglycone specificity in maize and sorghum $\beta$ glucosidases. J Biol Chem 278(27):25055-25062. https://doi.org/10.1074/jbc. M301978200

9. Naumoff DG (2011) Hierarchical classification of glycoside hydrolases. Biochemistry 76(6):622-635. https://doi.org/10.1134/S0006297911060022

10. Sestelo ABF, Poza M, Villa TG (2004) B-Glucosidase activity in a lactobacillus plantarum wine strain. World J Microbiol Biotechnol 20:633. https://doi. org/10.1023/b:wibi.0000043195.80695.17

11. Abouloifa H, Rokni Y, Bellaouchi R, Hasnaoui I, Gaamouche S, Ghabbour N, Chaoui J, Brasca M, Karboune S, Salah RB (2020) Technological properties of potential probiotic lactobacillus strains isolated from traditional fermenting green olive. J Microbiol Biotechnol Food Sci 9(1):884-889. https://doi.org/1 0.15414/jmbfs.2020.10.1.22-27

12. Landete JM, Rodríguez H, Curiel JA, Rivas B d I, de Felipe FL, Muñoz R (2021) Degradation of phenolic compounds found in olive products by Lactobacillus plantarum strains. https://doi.org/10.1016/b978-0-12-819528-4. 00028-6133-144 10.1016/b978-0-12-819528-4.00028-6

13. Rodriguez-Gomez F, Romero-Gil V, Bautista-Gallego J, Garrido-Fernandez A, Arroyo-Lopez FN (2012) Multivariate analysis to discriminate yeast strains with technological applications in table olive processing. World J Microbiol Biotechnol 28(4):1761-1770. https://doi.org/10.1007/s11274-011-0990-1

14. Erdemir Tıraş ZŞ, Kalkan Yıldııı H (2021) Application of mixed starter culture for table olive production. Grasas Aceites 72(2):e405. https://doi. org/10.3989/gya.0220201

15. Ghabbour N, Lamzira Z, Thonart P, Cidalia P, Markaoui M, Asehraou A (2011) Selection of oleuropein-degrading lactic acid bacteria strains isolated from fermenting Moroccan green olives. Grasas Aceites 62(1):84-89. https://doi. org/10.3989/gya.055510

16. Ghabbour N, Rokni Y, Lamzira Z, Thonart P, Chihib NE, Peres C, Asehraou A (2016) Controlled fermentation of Moroccan picholine green olives by oleuropein-degrading Lactobacilli strains. Grasas Aceites 67(2):e138. https:// doi.org/10.3989/gya.0759152

17. Rokni Y, Ghabbour N, Chihib N-E, Thonart P, Asehraou A (2015) Physicochemical and microbiological characterization of the natural fermentation of Moroccan Picholine green olives variety. J Mater Environ Sci 6:1740-1751

18. Alfano G, Lustrato G, Lima G, Vitullo D, Ranalli G (2011) Characterization of composted olive mill wastes to predict potential plant disease suppressiveness. Biol Control 58(3):199-207. https://doi.org/10.1016/j. biocontrol.2011.05.001

19. Principi P, Ranalli G, da Borso F, Pin M, Zanardini E, Sorlini C (2003) Microbiological aspects of humid husk composting. J Environ Sci Heal B 38(5):645-661. https://doi.org/10.1081/PFC-120023521

20. Ahmadova A, Todorov SD, Choiset $Y$, Rabesona H, Zadi TM, Kuliyev A, de Melo Franco BDG, Chobert J-M, Haertlé T (2013) Evaluation of antimicrobial activity, probiotic properties and safety of wild strain Enterococcus faecium AQ71 isolated from Azerbaijani Motal cheese. Food Control 30(2):631-641. https://doi.org/10.1016/j.foodcont.2012.08.009

21. Devoyod JJ, Poullain F $(1988,68)$ The Leuconostocs. Characteristics, their role in dairy technology. Lait (France):249-279. https://doi.org/10.1051/lait:1988317

22. Pchelintsev NA, Adams PD, Nelson DM (2016) Critical Parameters for Efficient Sonication and Improved Chromatin Immunoprecipitation of High Molecular Weight Proteins. PLoS One 11(1):e0148023. https://doi.org/10.13 71/journal.pone.0148023

23. Laemmli UK (1970) Cleavage of Structural Proteins during the Assembly of the Head of Bacteriophage T4. Nature 227(5259):680-685. https://doi.org/1 $0.1038 / 227680 \mathrm{a} 0$

24. Wray W, Boulikas T, Wray VP, Hancock R (1981) Silver staining of proteins in polyacrylamide gels. Anal Biochem 118(1):197-203. https://doi.org/10.1016/ 0003-2697(81)90179-2

25. Norkrans B (1950) Influence of cellulolytic enzymes from Hymenomycetes on cellulose preparations of different crystallinity. Physiol Plant 3(1):75-87. https://doi.org/10.1111/j.1399-3054.1950.tb07494.x 
26. Sánchez-Moreno C, Larrauri JA, Saura-Calixto F (1998) A procedure to measure the antiradical efficiency of polyphenols. J Sci Food Agric 76(2): 270-276. https://doi.org/10.1002/(SICI)1097-0010(199802)76:2<270::AID-JSFA $945>3.0 . C O ; 2-9$.

27. Lamzira Z (2010) Contribution au contrôle du processus de fermentation des olives vertes de table de la variété Picholine marocaine et caractérisation de son profil polyphénolique. PhD Thesis, Université Mohamed Premier, Oujda

28. Edberg SC, Gam K, Bottenbley CJ, Singer JM (1976) Rapid spot test for the determination of esculin hydrolysis. J Clin Microbiol 4(2):180-184. https:// doi.org/10.1128/jcm.4.2.180-184.1976

29. Gikas E, Papadopoulos N, Tsarbopoulos A (2007) Kinetic Study of the Acidic Hydrolysis of Oleuropein, the Major Bioactive Metabolite of Olive Oil. J Liq Chromatogr Rel Technol 29(4):497-508. https://doi.org/10.1080/1082 6070500474113

30. Abriouel H, Benomar N, Cobo A, Caballero N, Fernandez Fuentes MA, PerezPulido R, Galvez A (2012) Characterization of lactic acid bacteria from naturally-fermented Manzanilla Alorena green table olives. Food Microbiol 32(2):308-316. https://doi.org/10.1016/j.fm.2012.07.006

31. Peres CM, Alves M, Hernandez-Mendoza A, Moreira L, Silva S, Bronze MR, Vilas-Boas L, Peres C, Xavier Malcata F (2014) Novel isolates of lactobacilli from fermented Portuguese olive as potential probiotics. LWT - Food Sci Technol 59(1):234-246. https://doi.org/10.1016/j.Iwt.2014.03.003

32. Tofalo R, Perpetuini G, Schirone M, Ciarrocchi A, Fasoli G, Suzzi G, Corsetti A (2014) Lactobacillus pentosus dominates spontaneous fermentation of Italian table olives. LWT - Food Sci Technol 57(2):710-717. https://doi.org/1 0.1016/j.lwt.2014.01.035

33. Abouloifa H, Rokni Y, Bellaouchi R, Ghabbour N, Karboune S, Brasca M, Salah RB, Chihib NE, Saalaoui E, Asehraou A (2020) Characterization of probiotic properties of antifungal Lactobacillus strains isolated from traditional fermenting green olives. Probiotics and antimicrobial proteins 12(2):683696. https://doi.org/10.1007/s12602-019-09543-8

34. Tofalo R, Perpetuini G, Schirone M, Suzzi G, Corsetti A (2013) Yeast biota associated to naturally fermented table olives from different Italian cultivars. In J Food Microbiol 161(3):203-208. https://doi.org/10.1016/j.ijfoodmicro.2 012.12 .011

35. Bonatsou S, Benítez A, Rodríguez-Gómez F, Panagou EZ, Arroyo-López FN (2015) Selection of yeasts with multifunctional features for application as starters in natural black table olive processing. Food Microbiol 46:66-73. https://doi.org/10.1016/j.fm.2014.07.011

36. Kiai H, Hafidi A (2014) Chemical composition changes in four green olive cultivars during spontaneous fermentation. LWT - Food Sci Technol 57(2): 663-670. https://doi.org/10.1016/j.lwt.2014.02.011

37. Coulon S, Chemardin P, Gueguen Y, Arnaud A, Galzy P (1998) Purification and characterization of an intracellular $\beta$-glucosidase from Lactobacillus casei ATCC 393. Appl Biochem Biotechnol 74(2):105-114. https://doi.org/10.1 007/BF02787177

38. Michlmayr H, Schumann C, da Silva NM, Kulbe KD, del Hierro AM (2010) Isolation and basic characterization of a beta-glucosidase from a strain of Lactobacillus brevis isolated from a malolactic starter culture. J Appl Microbiol 108(2):550-559. https://doi.org/10.1111/j.1365-2672.2009.04461x x

39. Leah R, Kigel J, Svendsen I, Mundy J (1995) Biochemical and molecular characterization of a barley seed beta-glucosidase. The Journal of biological chemistry 270(26):15789-15797. https://doi.org/10.1074/jbc.270.26.15789

40. Boonclarm D, Sornwatana T, Arthan D, Kongsaeree P, Svasti J (2006) BGlucosidase Catalyzing Specific Hydrolysis of an Iridoid $\beta$-Glucoside from Plumeria obtusa. Acta Biochim Biophys Sin 38(8):563-570. https://doi.org/1 0.1111/j.1745-7270.2006.00196.x

41. Esteban-Torres M, Reveron I, Mancheno JM, de Las Rivas B, Munoz R (2013) Characterization of a feruloyl esterase from Lactobacillus plantarum. Appl Environ Microbiol 79(17):5130-5136. https://doi.org/10.1128/AEM.01523-13

42. Johnson R, Melliou E, Zweigenbaum J, Mitchell AE (2018) Quantitation of oleuropein and related phenolics in cured Spanish-style green, californiastyle black ripe, and greek-style natural fermentation olives. J Agric Food Chem 66(9):2121-2128. https://doi.org/10.1021/acs.jafc.7b06025

43. Soni MG, Burdock GA, Christian MS, Bitler CM, Crea R (2006) Safety assessment of aqueous olive pulp extract as an antioxidant or antimicrobial agent in foods. Food Chem Toxicol 44(7):903-915. https://doi.org/10.1016/j. fct.2006.01.008
44. Hu T, He XW, Jiang JG, Xu XL (2014) Hydroxytyrosol and its potential therapeutic effects. J Agric Food Chem 62(7):1449-1455. https://doi.org/10.1 021/jf405820v

45. Ponomarova O, Gabrielli N, Sévin DC, Mülleder M, Zirngibl K, Bulyha K Andrejev S, Kafkia E, Typas A, Sauer U, Ralser M, Patil KR (2017) Yeast creates a niche for symbiotic lactic acid bacteria through nitrogen overflow. Cell Systems 5:345-357.e6. https://doi.org/10.1016/j.cels.2017.09.002

46. D'Souza G, Shitut S, Preussger D, Yousif G, Waschina S, Kost C (2018) Ecology and evolution of metabolic cross-feeding interactions in bacteria. Nat Prod Rep 35(5):455-488. https://doi.org/10.1039/C8NP00009C

47. Gouripur G, Kaliwal B (2017) Screening and optimization of $\beta$-glucosidase producing newly isolated Lactobacillus plantarum strain LSP-24 from colostrum milk. Biocatal Agric Biotechnol 11:89-96. https://doi.org/10.1016/j. bcab.2017.06.007

48. Saha BC, Bothast RJ (1996) Production, purification, and characterization of a highly glucose-tolerant novel beta-glucosidase from Candida peltata. Appl Environ Microbiol 62(9):3165-3170. https://doi.org/10.1128/aem.62.9.3165-31 70.1996

49. Pandey M, Mishra S (1997) Expression and characterization of Pichia etchellsil ß-glucosidase in Escherichia coli. Gene 190(1):45-51. https://doi.org/10.1016/ S0378-1119(96)00712-3

50. Boonclarm D, Svasti J (2002) Screening of thai plants for natural betaglucosides and beta-glucosidase enzyme. PhD Thesis, Mahidol University, Thaillande

51. Yuksekdag Z, Acar BC, Aslim B, Tukenmez U (2018) $\beta$-Glucosidase activity and bioconversion of isoflavone glycosides to aglycones by potential probiotic bacteria. Int J Food Prop 20(sup3):S2878-S2886. https://doi.org/1 0.1080/10942912.2017.1382506

52. Restuccia C, Muccilli S, Palmeri R, Randazzo CL, Caggia C, Spagna G (2011) An alkaline $\beta$-glucosidase isolated from an olive brine strain of Wickerhamomyces anomalus. FEMS Yeast Research 11(6):487-493. https:// doi.org/10.1111/j.1567-1364.2011.00738.x

53. Umezurike GM (1987) The mechanism of action of beta-glucosidase from Botryodiplodia theobromae Pat. Biochem J 241(2):455-462. https://doi.org/1 0.1042/bj2410455

54. Dietz K-J, Sauter A, Wichert K, Messdaghi D, Hartung W (2000) Extracellular $\beta$-glucosidase activity in barley involved in the hydrolysis of ABA glucose conjugate in leaves. J Exp Bot 51(346):937-944. https://doi.org/10.1093/ jexbot/51.346.937

55. Bowers EM, Ragland LO, Byers LD (2007) Salt effects on beta-glucosidase: pH-profile narrowing. Biochim Biophys Acta 1774(12):1500-1507. https://doi. org/10.1016/j.bbapap.2007.10.007

\section{Publisher's Note}

Springer Nature remains neutral with regard to jurisdictional claims in published maps and institutional affiliations.

\section{Submit your manuscript to a SpringerOpen ${ }^{\circ}$ journal and benefit from:}

- Convenient online submission

- Rigorous peer review

- Open access: articles freely available online

- High visibility within the field

- Retaining the copyright to your article

Submit your next manuscript at $>$ springeropen.com 